\title{
Manajemen Asuhan Keperawatan Jiwa Pada Ny. M Dengan Masalah Isolasi Sosial Di Desa Dahana Kec.Gunungsitoli Idanoi Kota Gunungsitoli
}

\author{
Delvin Haryani Lombu
}

Delvyn25lombu@gmail.com

\section{BAB 1 \\ PENDAHULUAN}

\subsection{Latar Belakang}

Skizofrenia merupakan sekelompok reaksi psikotik yang mempengaruhi berbagai area fungsi individu, termasuk berpikir, berkomunikasi, menerima, menginterpretasikan realitas, merasakan dan menunjukkan emosi serta penyakit kronis, parah, dan melumpuhkan, gangguan otak yang ditandai dengan pikiran kacau, waham, halusinasi, dan perilaku aneh (Pardede. 2018). Hasil Riskesdas (2018) didapatkan estimasi prevalensi orang yang pernah menderita skizofrenia di Indonesia sebesar 1,8 per 1000 penduduk. Hasil survey awal yang dilakukan di poliklinik rawat jalan Rumah Sakit Jiwa Medan di temukan sebanyak 13.899 pasien yang rawat jalan dibawa oleh keluarganya untuk berobat (Pardede, 2020).

Skizofrenia merupakan sekelompok reaksi psikotik yang memengaruhi berbagai area fungsi individu, termasuk berpikir, berkomunikasi, mau untuk menerima, menginterpretasikan realitas, merasakan dan menunjukkan emosi. Pasien skizofrenia sering mendapat stigma dan diskriminasi yang lebih besar dari masyarakat sekitarnya dibandingkan individu yang menderita penyakit medis lainnya. Penderita skizofrenia biasanya timbul pada usia sekitar 18-45 tahun, dan berusia 11-12 tahun menderita skizofrenia (Pardede, 2016). Gejala negatif dari skizofrenia adalah isolasi sosial. Isolasi sosial sebagai gejala negatif pada skizofrenia yang digunakan oleh pasien untuk menghindari orang lain karena pengalaman yang tidak menyenangkan sehingga tidak berurusan dengan orang lain lagi. Menarik diri digunakan oleh pasien untuk menghindari 
orang lain sehingga pengalaman yang tidak menyenangkan dalam berhubungan dengan orang lain jangan terjadi lagi (Pardede \& Ramadia, 2021).

Survei awal pada pembuatan askep pada skizofrenia ini dilakukan di jalan Turendra Desa Dahana Kec. Gunungsitoli Idanoi Kota Gunungsitoli . Subjek didalam pembuatan askep ini berjumlah satu orang dengan pasien atas nama inisial $\mathrm{Ny}$. M pasien yang sering menyendiri, mengurung diri dikamar, tidak mau bersosialisasi dan didiagnosa dengan isolasi sosial. Penyebab Ny. M dijadikan sebagai subjek dikarenakan pasien belum mampu berinteraksi dengan orang lain.

\subsection{Rumusan Masalah}

Berdasarkan latar belakang masalah tersebut maka dapat dirumuskan masalah sebagai berikut: bagaimana pemberian asuhan keperawatan jiwa pada $\mathrm{Ny}$. $\mathrm{M}$ dengan isolasi Sosial

\subsection{Tujuan}

\subsubsection{Tujuan Umum}

Setelah mengikuti kegiatan ini pasien dapat lebih menerapkan stategi pelaksanaan Isolasi Sosial dalam mengontrol Perilaku Isolasi Sosial.

\subsubsection{Tujuan Khusus}

1. Mahasiswa mampu mengetahui defenisi, tanda dan gejala, faktor penyebab, mekanisme koping, penatalaksanaan pada pasien dengan Isolasi Sosial.

2. Mahasiswa mampu melakukan pengkajian kepada kpasien dengan Isolasi Sosial.

3. Mahasiswa mampu menegakkan diagnosa atau masalah keperawatan kepada Ny.M dengan Isolasi Sosial.

4. Mahasiswa mampu menetapkan Intervensi keperawatan secara menyeluruh kepada Ny. M dengan Isolasi Sosial.

5. Mahasiswa mampu melakukan tindakan keperawatan sesuai Intervensi keperawatan yang ditetapkan secara menyeluruh kepada Ny. M dengan Isolasi Sosial. 
6. Mahasiswa mampu mengevaluasi sebagai tolak ukur guna menerapkan asuhan keperawatan pada Ny. M dengan Isolasi Sosial.

\subsection{Manfaat}

Pasien Diharapkan tindakan yang telah di ajarkan dapat diterapkan secara mandiri untuk mengontrol emosi dan untuk mendukung kelangsungan kesehatan pasien. 


\section{BAB 2}

\section{TINJAUAN TEORITIS}

\subsection{Konsep Isolasi Sosial}

\subsubsection{Pengertian}

Isolasi sosial adalah keadaan dimana individu mengalami penurunan atau bahkan sama sekali tidak mampu berinteaksi dengan orang lain disekitarnya (Damaiyanti, 2012). Klien mungkin merasa ditolak, tidak diterima, kesepian, dan tidak mampu membina hubungan yang berarti dengan orang lain. Isolasi sosial juga merupakan kesepian yang dialami individu dan dirasakan saat didorong oleh keberadaan orang lain sebagai pernyataan negatif atau mengancam (Damanik, Pardede \& Manalu, 2020).

Isolasi sosial merupakan keadaan dimana seorang individu mengalami penurunan atau bahkan sama sekali tidak mampu berinteraksi dengan orang lain di sekitarnya. Klien mungkin merasa ditolak, tidak diterima, kesepian, dan tidak mampu membina hubungan yang berarti dengan orang lain (Pardede, 2018).

Jadi, dapat disimpulkan bahwa isolasi sosial merupakan keaadaan seseorang yang mengalami penurunan bahkan sama sekali tidak mampu berinteraksi dengan orang lain karena mungkin merasa ditolak, kesepian dan tidak mampu menjalin hubungan yang baik antar sesama.

\subsubsection{Tanda dan Gejala}

Menurut Sukaesti, (2019), tanda dan gejala yang dimilki isolasi social adalah sebagai berikut :

1. Wajah murung

2. Sulit tidur

3. Gelisah 


\section{Lemah}

5. Kurang bergairah, dan

6. Malas beraktifitas

7. Menarik diri

8. Menjauhi orang lain

9. Tidak atau jarang melakukan komunikasi tidak ada kontak mata,

10. Kehilangan minat,

11. Malas melakukan kegiatan sehari-sehari atau aktivitas sosial,

12. Berdiam diri di kamar,

13. Menolak hubungan dengan orang lain, dan

14. Tidak mau menjalin persahabatan.

\subsubsection{Etiologi}

Peyebab dari isolasi sosial yaitu peranan negatif tentang diri sendiri, hilang kepercayaan diri, merasa gagal mencapai keinginan, yang ditandai dengan adanya perasaan malu terhadap diri sendiri, rasa bersalah terhadap diri sendiri, gangguan hubungan sosial, merendahkan martabat, percaya diri kurang dan juga cepat mencederai diri (Muhith, 2015)

1. Faktor Predisposisi Beberapa faktor predispoisi (pendukung ) terjadi gangguan hubungan yaitu : Faktor Perkembangan. Kemampuan membina hubungan yang sehat tergantung dari pengalaman selama proses tumbuh kembang. Setiap tahap tumbuh kembang memiliki tugas yang harus dilalui individu dengan sukses, karena apabila tugas perkembangan ini tidak dapat dipenuhi akan menghambat masa perkembangan selanjutnya. Kurangnya stimulasi, kasih sayang, perhatian, dan kehangatan dari orang tua pengasuh akan memberikan rasa tidak aman yang dapat menghambat terbentuknya rasa tidak percaya.

a. Faktor Biologis, genetik merupakan salah satu faktor pendukung gangguan jiwa. Kelainan struktur otak seperti atrofi, pembesaran vetrikel, penurunan berat dan volume otak serta perubahan limbik diduga dapat menyebabkan skizofrenia

b. Faktor Sosial Budaya, faktor sosial budaya dapat menjadi faktor pendukung terjadinya gangguan dalam membina hubungan dengan orang lain, misalnya anggota keluarga yang tidak produktif diasingkan dari orang lain (Lingkungan sosial) (Muhith, 2015) 
c. faktor Lain

d. Faktor Genetik dianggap mempunyai transmin gangguan efektif melalui riwayat keluarga dan keturunan.

2. Stresor Presipitasi

a. Stresor Sosial Budaya, stresor sosial budaya dapat menyebabkan terjadinya gangguan dalam membina hubungan dengan orang lain. Misalnya anggota keluarga yang labil yang dirawat dirumah sakit (Muhith, 2015)

b. Stresor Psikologis, tingkat kecemasan yang berat akan menyebabkan menurunnya kemampuan individu untuk berhubungan dengan orang lain. Interaksi kecemasan yang ekstrem dan memanjang disertai terbatasnya kemampuan individu untuk mengatasi masalah diyakini untuk menimbulkan berbagai masalah gangguan hubungan (Muhith, 2015)

Rentang respon

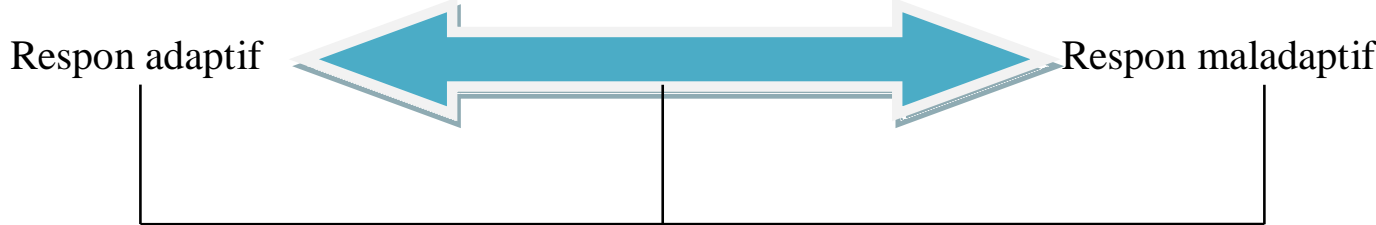

Menyendiri Otonomi Kesendirian Mengisolasi Manipulasi Impulsif Narkisisme Kebersamaan diri ketergantungan

\section{Respon adaptif}

Respon yang masih dapat diterima oleh norma norma sosial dan kebudayaan secara umum serta masih dalam batas normal dalam menyelesaikan masalah. Menyendiri : respon yang dibutuhkan seseorang untk merenungkan apa individu sehingga tidak dapat membina hubungan sosial secara mendalam. Curiga : Seseorang gagal mengembangkan rasa percaya terhadap orang lain (Iyus \& sutini, 2014)

\section{Tanda dan Gejala}
a. Gejala Subjektif
b. Klien menceritakan perasaan kesepian atau ditolak oleh orang lain
c. Klien merasa tidak aman berada dengan orang lain.
d. Tidak merawat diri dan tidak memperhatikan kebersihan diri
e. Mengisolasi diri 
f. Tidak atau kurang sadar terhadap lingkungan sekitarnya

g. Masukan makanan dan minuman terganggu

h. Retensi urin dan feses

i. Aktivitas menurun

j. Kurang Energi

k. Rendah diri (Iyus \& sutini, 2014)

\section{Mekanisme Koping}

Mekanisme koping digunakan klien sebagai usaha mengatasi mengatasi kecemasan yang merupakan suatu kesepian nyata yang mengancam dirinya. Kecemasan koping yang sering digunakan adalah regrasi, represi dan Isolasi. Sedangkan contoh sumber koping yang dapat digunakan misalnya keterlibatan dalam hubungan yang luas dalam keluarga dan teman, hubungan dengan hewan periharaan menggunakan kreatifitas untuk mengekspresikan stress interpersonal seperti kesenian musik atau tulisan (Duden, 2013).

\subsection{Diagnosa Keperawatan}

Menurut Sutejo (2017) adapun daftar masalah keperawatan pada pasien dengan isolasi sosial sebagai berikut:

1. Isolasi Sosial

2. Gangguan konsep diri: harga diri rendah

3. Resiko gangguan sensori persepsi: halusinasi

\subsection{Perencanaan Keperawatan}

1. Perencanaan keperawatan Perencanaan keperawatan merupakan serangkaian tindakan yang dapat mencapai setiap tujuan khusus. Perawat dapat memberikan alasan il miah terbaru dari tindakan yang diberikan. Alasan ilmiah merupakan pengetahuan yang berdasarkan pada literatur, hasil penelitian atau pengalaman praktek (Haebahan, 2020).

2. Penatalaksanaan Medis Jenis penatalaksanaan yang biasa dilakukan dalam kelompok penyakit skizofrenia termasuk isolasi sosial adalah (Ayuningtyas, 2020) :

a) Psikofarmaka Adalah terapi dengan menggunakan obat, tujuannya untuk mengurangi atau menghilangkan gejala-gejala gangguan jiwa. Yang tergolong 
dalam pengobatan psikofarmaka antara lain :

1) Chlorpromazine (CPZ) Atas indikasi untuk sindrom psikosis yaitu berdaya berat untuk menilai realistis, waham halusinasi, gangguan perasaan dan perilaku atau tidak terkendali tidak mampu bekerja. Dengan efek samping hipotesis, epilepsy, kelainan jantung, febris, ketergantungan obat.

2) Haloperidol (HLP) Atas indikasi berdaya berat dalam kemampuan menilai realita dalam fungsi mental serta dalam fungsi kehidupan sehari-hari dengan efek samping yaitu : penyakit hati, penyakit darah (anemia, leucopenia, agranulositosis), epilepsy, kelainan jantung, febris, dan ketergantungan obat.

3) Tryhexipenidil (THP) Atas indikasi segala jenis perkinson, termasuk pasca encephalitis dengan efek samping yaitu mulut kering, penglihatan kabur, pusing, mual, muntah, bingung, agitasi, konstipasi, takikardia, dilatasi, ginjal, retensi urin. Kontra indikasinya yaitu hipersensitif terhadap tryhexipenidil, glukosa sudut sempit, hipertropi prostate dan obstruksi saluran cerna.

3. Pemeriksaan Penunjang (ECT / Psikotherapy) Menurut Astuti, (2020) merupakan pengobatan untuk menurunkan kejang grandial yang menghasilkan efek samping tetapi dengan menggunakan arus listrik. Tujuan untuk memperpendek lamanya skizofrenia dan dapat mempermudah kontak dengan orang lain. Dengan kekuatan 75 - 100 volt, ECT diberikan pada pasien dengan indikasi depresi berat dan terapi obat sebelumnya tidak berhasil, pasien akan beresiko bunuh diri dan skizofrenia akut.

\subsection{Konsep Asuhan Keperawatan Jiwa}

Pengkajian Keperawatan Pengkajian adalah sebagai dasar utama dari proses keperawatan. Tahap pengkajian terdiri dari pengumpulan data dan perumusan masalah pasien. Data yang dikumpulkan melalui data biologis, psikologis, sosial dan spiritual (Saputri \& Mar'atus, 2021)

\subsection{Analisa Data}

Analisa Data Dengan melihat data subyektif dan objektif dapat menentukan permasalahan yang dihadapi pasien. Dan dengan memperhatikan pohon masalah dapat diketahui penyebab, affeck dari masalah tersebut. Dari 12 hasil analisa data inilah 
dapat ditentukan diagnosa keperawatan (Hasannah, 2019).

\section{BAB 3}

\section{TINJAUAN KASUS}

\subsection{Identitas Pasien}

$\begin{array}{ll}\text { Inisial } & : \text { Ny.M } \\ \text { Jenis kelamin } & : \text { Perempuan } \\ \text { Umur } & : \text { 52 Tahun } \\ \text { Agama } & : \text { Kristen Protestan } \\ \text { Status } & : \text { Lajang } \\ \text { Tanggal pengkajian } & : \text { 05 Maret 2021 } \\ \text { Informant } & : \text { komunikasi dengan pasien. }\end{array}$

\subsection{Alasan Masuk}

Pasien tidak masuk ruamah sakit atau yayasan pemulihan kasih yang terdapat di Kota Gunungsitoli dikarenakan pasien tidak mau dan keluarga tidak memiliki uang untuk biaya masuk ke dalam yayasan tersebut.

\subsection{Faktor Predisposisi}

Pasien mengalami ganguan jiwa sejak usia 14tahun yang lalu. Dirumah pasien tidak mau kontrol ke RSJ atau yayasa pemulihan kasih yang terdapat di Kota Gunungsitoli sehingga timbul gejala-gejala seperti diatas. Keluarga pasien tidak ada yang pernah mengalami gangguan jiwa. Masalah Keperawatan: isolasi sosial

\subsection{Fisik Pasien}

Pasien tidak memiliki keluhan fisik, saat dilakukan pemeriksaan tanda-tanda vital, didapatkan hasil TD : 110/80 mmHg ; $\mathrm{N}: 82 \mathrm{x} / \mathrm{i} ; \mathrm{S}: 36,7 \mathrm{oC} ; \mathrm{P}: 22 \mathrm{x} / \mathrm{i}$. Pasien memiliki tinggi badan $157 \mathrm{~cm}$ dan berat badan $45 \mathrm{Kg}$. 


\section{5 Psikososial}

\subsubsection{Genogram}

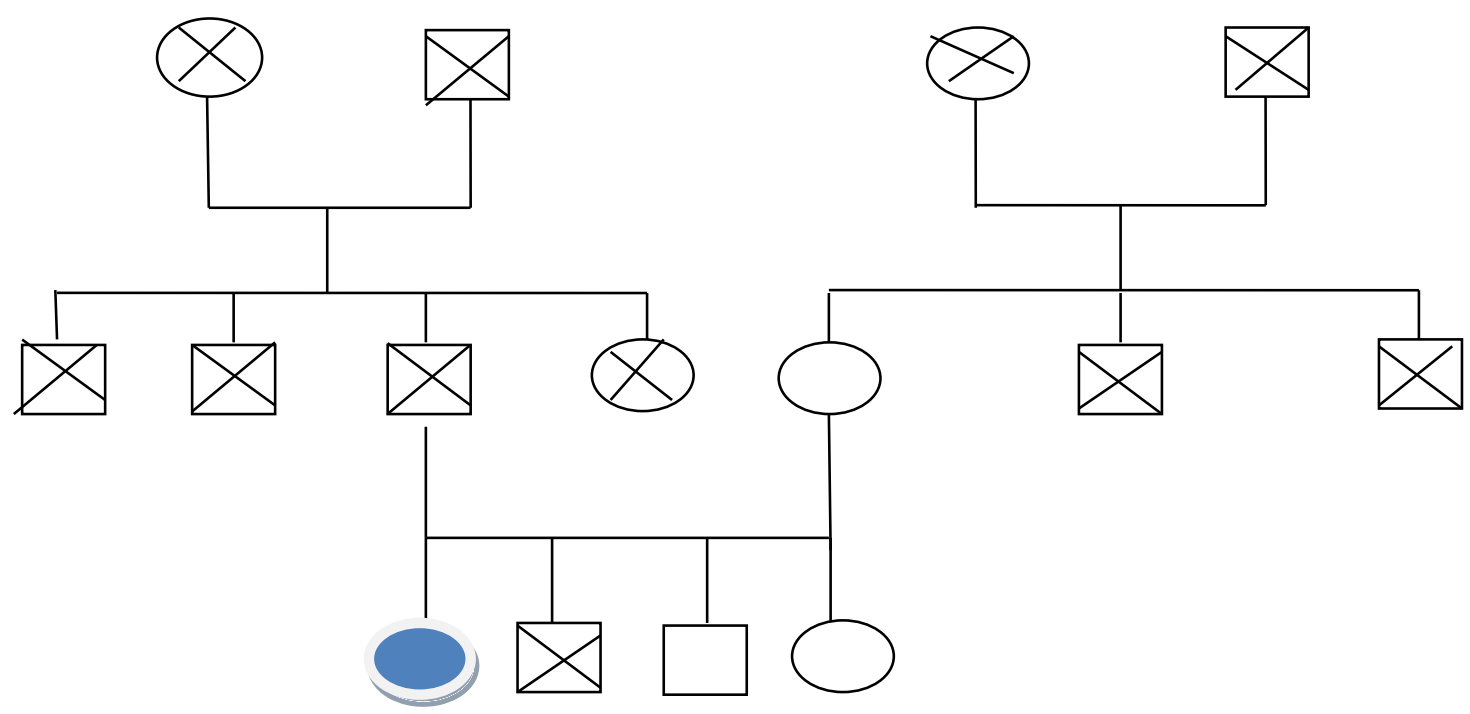

Penjelasan :

Pasien anak pertama dari 4 bersaudara, pasien berinisial Ny. M, pasien memiliki ibu sedangkan ayah pasien sudah meninggal dunia dan saat usia pasien 52 tahun. Ny.M belum menikah.

Keterangan :
Laki-Laki
$\bigcirc$ Perempuan
(1) Pasien
- Garis keturunan
$>$ Meninggal

\subsubsection{Konsep diri}

a. Gambaran diri : Tidak ada kecacatan

b. Identitas : Pasien anak ke 1 dari 4 bersaudara, pasien hanya lulusan SD yang saat ini dirawat di rumah

c. Peran : Pasien berperan sebagai anak dan masih lajang, pasien tinggal bersama keluarganya

d. Ideal diri : Pasien merasa takut pada orang di sekitarnya yang baru dia lihat 
e. Harga diri : Pasien merasa malu dan takut saat di lakukan komunikasi

\subsubsection{Hubungan Sosial}

Pasien mengganggap bahwa keluarganya adalah orang yang sangat berarti dalam hidupnya, terutama ibunya. Pasien tidak memiliki teman . Pasien mengatakan tidak pernah bersosialisasi dengan teman teman di lingkungan kerjanya, dan tidak mau mempunyai teman dan ingin sendiri, pasien tidak suka bergaul bergaul Masalah keperawatan: Isolasi Sosial

\subsubsection{Spiritual}

a. Nilai dan Keyakinan :Pasien beragama kristen protestan dan yakin dengan agamanya.

b. Kegiatan Ibadah :Ibadah 2 kali sehari, yaitu pagi saat bangun, dan sebelum tidur

\subsubsection{Status Mental}

a. Penampilan Pasien berpenampilan rapi tapi bau

b. Pembicaraan Pasien masih mampu menjawab pertanyaan perawat dengan lambat namun dapat dipahami dan dapat dimengerti dengan baik.

c. Aktivitas Motorik Pasien terlihat diam, menundukkan kepala

d. Suasana perasaan Pasien kadang sedih jika tidak di perhatiakan oleh ibunya

e. Masalah keperawatan : Harga Diri Rendah

f. Afek Afek pasien labil, mudah emosi, mudah marah pada saat meminta makan untuk makan. Masalah keperawatan : Risiko perilaku kekerasan

g. Interaksi selama wawancara Pasien kooperatif, tidak ada kontak mata pada lawan bicara, tidak mudah tersinggung dalam setiap interaksi.

h. Persepsi Pasien sering mendengar suara-suara tampa wajah yang menyuruhnya untuk beribadah. Masalah keperawatan : gangguan persepsi sensori: Halusinasi h.

i. Proses Pikir Pasien mampu menjawab apa yang ditanya dengan baik.

j. Isi pikir Pasien dapat mengontrol isi pikirnya,pasien tidak mengalami gangguan isi pikir dan tidak ada waham. Pasien tidak

k. Tingkat kesadaran Pasien tidak mengalami gangguan orientasi, pasien mengenali waktu, orang dan tempat.

1. Memori Pasien mampu menceritakan kejadian di masa lalu dan yang baru terjadi.

$\mathrm{m}$. Tingkat konsentrasi berhitung Pasien mampu berkonsentrasi dalam perhitungan sederhana tanpa bantuan orang lain.

n. Kemampuan penilaian Pasien dapat membedakan hal yang baik dan yang buruk.

o. Daya tilik diri Pasien tidak mengetahui penyakit yang dideritanya, pasien mengetahui bahwa dia sering menyendiri dan tidak suka bersosialisasi.

\subsection{Mekanisme Koping}

Pasien mengalami mekanisme koping yaitu pasien tidak dapat berbicara baik dengan orang lain.

\subsection{Pengetahuan}

Kurang Tentang Gangguan Jiwa Pasien tidak mengetahui tentang gangguan jiwa yang di alaminya dan pasien tidak tau apa obat yang dikonsumsinya. 


\subsection{Analisis Data}

\begin{tabular}{|l|l|l|}
\hline No & \multicolumn{1}{|c|}{ Data } & Masalah keperawatan \\
\hline 1 & $\begin{array}{l}\text { Subjektif : Pasien sering menyendiri, } \\
\text { bicara sendiri, bingung, sulit tidur, } \\
\text { tidak mau makan, jarang sekali } \\
\text { bergaul dengan lingkungan, karena } \\
\text { pasien merasa malu dan juga merasa } \\
\text { dirinya dimusuhi oleh sodaranya } \\
\text { kandungnya hingga akhirnya pasien } \\
\text { memukul adek kandungnya, terkadang } \\
\text { pasien juga marah-marah dan berteriak } \\
\text { jika dipaksa untuk makan dan minum } \\
\text { serta mandi. } \\
\begin{array}{l}\text { Objektif : Sering terlihat melamun, } \\
\text { pasien tampak bingung dan bicara } \\
\text { sendiri, pasien kurang kooperatif, } \\
\text { menundukan kepala saat wawancara, } \\
\text { dan pendiam dan suka }\end{array}\end{array}$ \\
\hline 2 & $\begin{array}{l}\text { Subjektif : Pasien mengatakan malu } \\
\text { dan malas berinteraksi dengan orang } \\
\text { lain. }\end{array}$ \\
$\begin{array}{l}\text { Objektif : Pasien tampak lemah dan } \\
\text { tidak bersemangat, kontak mata } \\
\text { kurang, pasien lebih sering } \\
\text { menyendiri. } \\
\text { Subjektif : Pasien mengatakan merasa } \\
\text { malu dan juga merasa dirinya } \\
\text { dimusuhi oleh adik kandungnya, } \\
\text { hingga akhirnya pasien memukul adik } \\
\text { kandungnya }\end{array}$ \\
$\begin{array}{l}\text { Objektif : Pasien tampak marah-marah } \\
\text { dan berteriak jika dipaksa untuk } \\
\text { makan dan minum }\end{array}$ \\
\hline
\end{tabular}

\subsection{Pohon masalah}

Resiko Perilaku Kekerasan

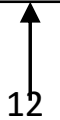




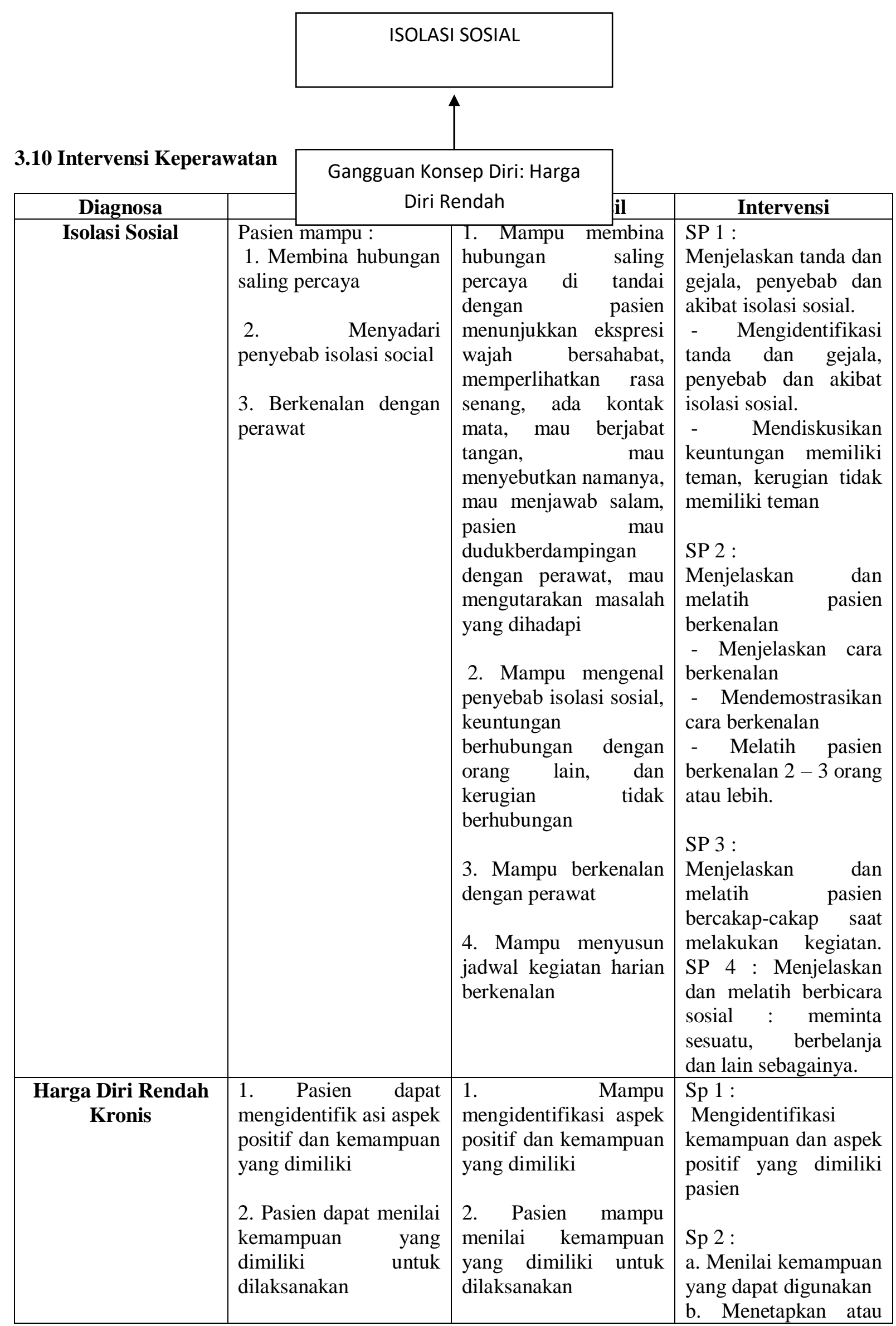




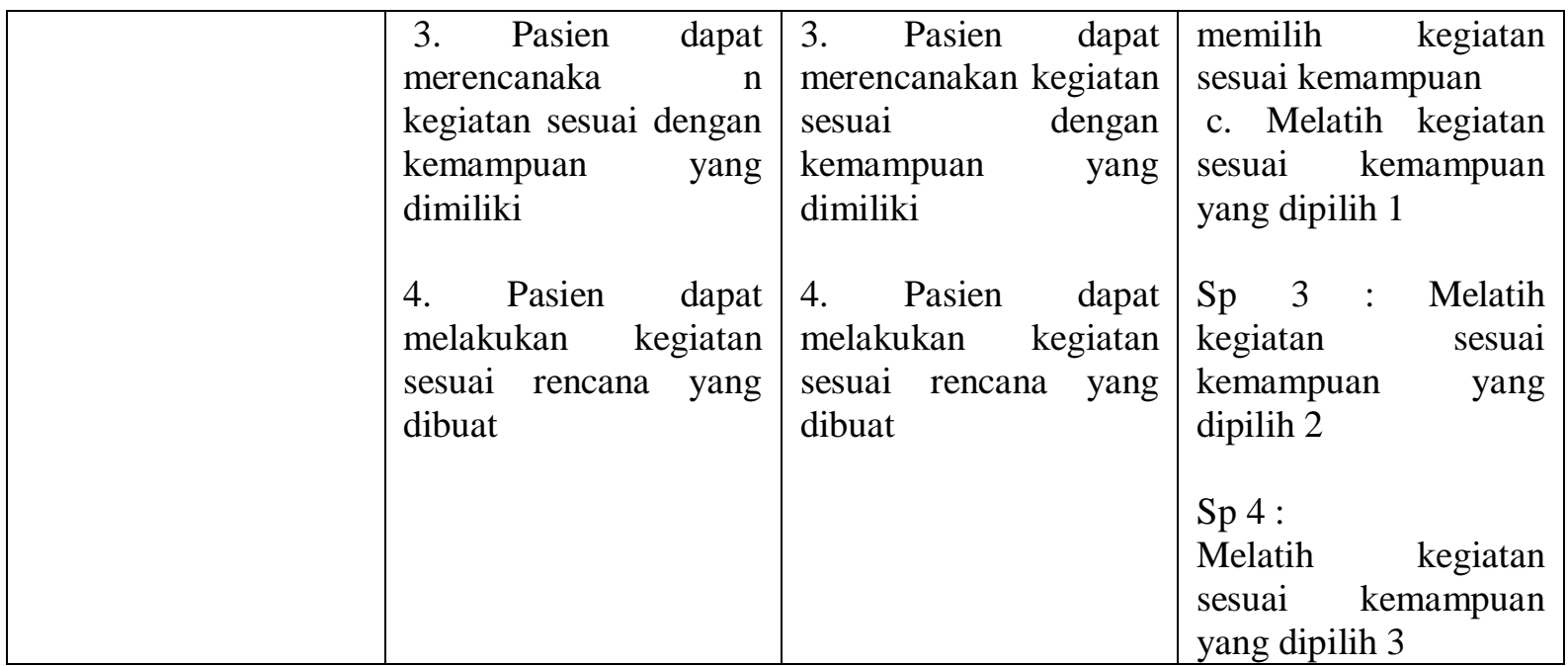

\subsection{Implementasi dan Evaluasi Keperawatan}

\begin{tabular}{|c|c|c|}
\hline Waktu & Implementasi & Evaluasi \\
\hline $\begin{array}{l}\text { Senin, } 8 \text { Maret } 2021 \text { Jam 10: } \\
\qquad 45 \text { wib }\end{array}$ & 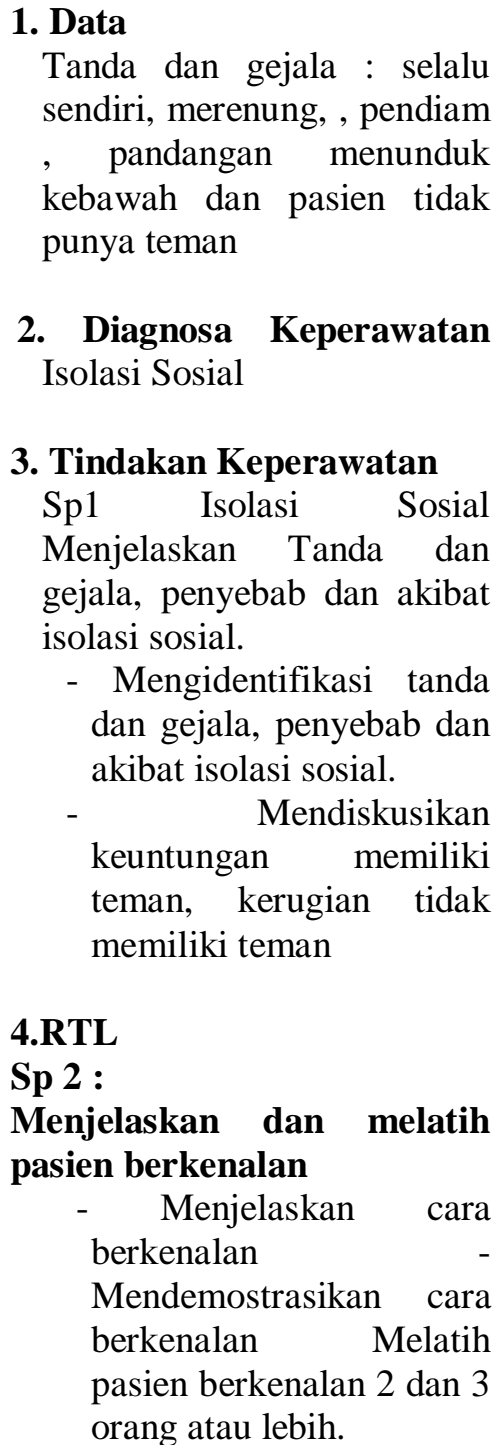 & $\begin{array}{l}\text { S : Lebih banyak diam, } \\
\text { pandangan menunduk } \\
\text { kebawah } \\
\text { O : - Pasien belum mampu } \\
\text { mengenali masalah isolasi } \\
\text { sosial dengan mandiri. } \\
\text { Mengidentifikasi isolasi } \\
\text { sosialnya; tanda dan gejala, } \\
\text { penyebab dan akibat dari } \\
\text { isolasi sosial } \\
\text { - Pasien belum mampu } \\
\text { menjelaskan Keuntungan } \\
\text { memiliki teman dan } \\
\text { kerugian memiliki teman } \\
\text { dengan mandiri. } \\
\text { A : Isolasi Sosial (+) } \\
\text { P : - Latihan mengidentifikasi } \\
\text { isolasi sosialnya; tanda } \\
\text { dan gejala, penyebab dan } \\
\text { akibat dari isolasi sosial } \\
\text { - Menjelaskan Keuntungan } \\
\text { memiliki teman dan } \\
\text { kerugian memiliki teman. }\end{array}$ \\
\hline
\end{tabular}




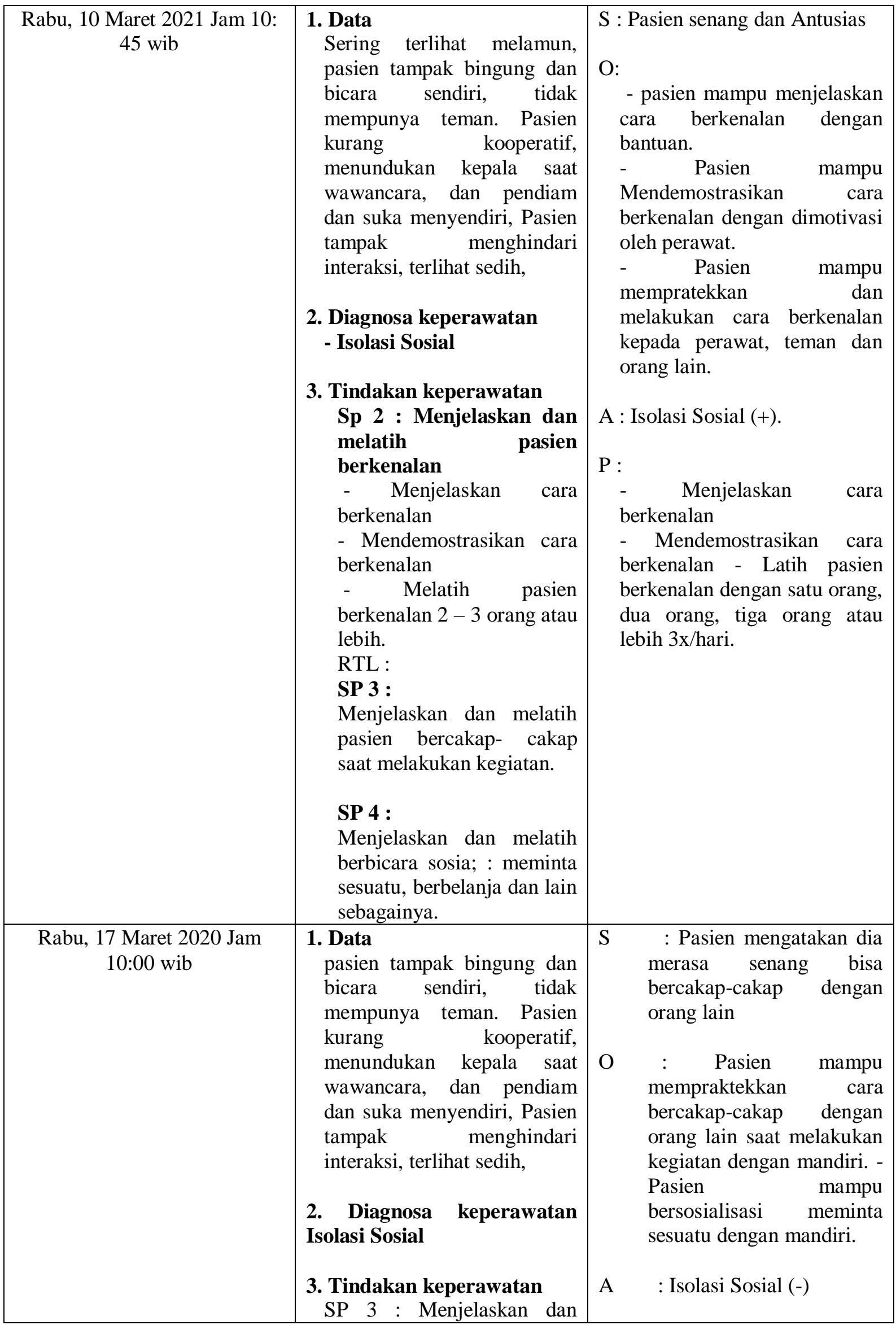




\begin{tabular}{|c|c|c|}
\hline & 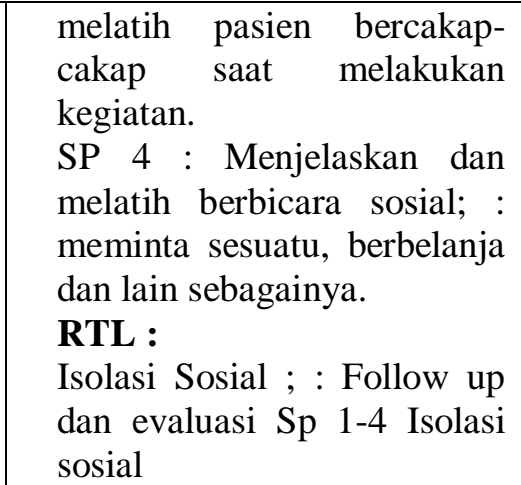 & $\begin{array}{ll}\mathrm{P} & \text { : Intervensi dilanjutkan } \\
& \text { - Latihan bercakap cakap } \\
& \text { sambil melakukan } \\
\text { kegiatan harian } 3 \mathrm{x} / \text { hari } \\
\text { - Latihan berbicara sosial } \\
\text { meminta sesuatu } 3 \mathrm{x} / \text { hari } \\
\text { - Latihan bercakap-cakap } \\
\text { dengan orang lain } 3 \mathrm{x} / \text { hari }\end{array}$ \\
\hline
\end{tabular}

\begin{tabular}{|c|c|c|}
\hline Hari/tgl & Implementasi & Evaluasi \\
\hline $\begin{array}{c}\text { Kamis, } 18 \text { Maret } 2021 \text { 10:30 } \\
\text { WIB }\end{array}$ & $\begin{array}{l}\text { 1. Data: } \\
\text { Tanda dan gejala : Hilang } \\
\text { kepercayaan diri, merasa } \\
\text { gagal karena tidak mampu } \\
\text { mencapai keinginan sesuai } \\
\text { ideal diri, perasaan tidak } \\
\text { berharga, tidak berarti dan } \\
\text { rendah diri yang } \\
\text { berkepanjangan } \\
\text { 2. Diagnosa Keperawatan } \\
\text { Harga Diri Rendah } \\
\text { 3. Tindakan keperawatan: } \\
\text { Sp } 1 \text { Harga Diri Rendah : } \\
\text { Mengidentifikasi } \\
\text { kemampuan dan aspek } \\
\text { positif yang dimiliki pasien } \\
\text { 4. RTL: } \\
\text { Sp2 Harga Diri Rendah: } \\
\text { a. Menilai kemampuan yang } \\
\text { dapat digunakan } \\
\text { b. Menetapkan atau memilih } \\
\text { kegiatan sesuai kemampuan } \\
\text { c. Melatih kegiatan sesuai } \\
\text { kemampuan yang dipilih } 1\end{array}$ & $\begin{array}{l}\text { S : Antusias dan bersemangat } \\
\text { O: Pasien mampu } \\
\text { Mengidentifikasi aspek positif } \\
\text { yang dimiliki pasien yaitu } \\
\text { berdoa dan bersyukur dengan } \\
\text { bantuan perawat } \\
\text { A : Harga Diri Rendah (+) } \\
\text { P : Pasien selalu memulai segala } \\
\text { aktivitas nya dengan } \\
\text { bersyukur dan Doa. }\end{array}$ \\
\hline $\begin{array}{c}\text { Kamis, } 18 \text { Maret } 2021 \text { 10:00 } \\
\text { WIB }\end{array}$ & $\begin{array}{l}\text { 1. Data: } \\
\text { Tanda dan gejala : Hilang } \\
\text { kepercayaan diri, merasa } \\
\text { gagal karena tidak mampu } \\
\text { mencapai keinginan sesuai } \\
\text { ideal diri, perasaan tidak } \\
\text { berharga, tidak berarti dan } \\
\text { rendah diri yang } \\
\text { berkepanjangan } \\
\text { Diagnosa Keperawatan } \\
\text { Harga Diri Rendah } \\
\text { 3. Tindakan keperawatan: }\end{array}$ & $\begin{array}{l}\text { S : Senang dan antusias } \\
\text { O : Pasien mampu memilih dan } \\
\text { melatih kegiatan sesuai } \\
\text { kemampuan yaitu masak } \\
\text { dengan bantuan } \\
\text { A : Harga Diri Rendah (+) } \\
\text { P : Pasien melatih kemampuan } \\
\text { memasak yang dimiliki nya }\end{array}$ \\
\hline
\end{tabular}




\begin{tabular}{|c|c|c|}
\hline & $\begin{array}{l}\text { Sp 2 Harga Diri Rendah : } \\
\text { a. Menilai kemampuan yang } \\
\text { dapat digunakan } \\
\text { b. Menetapkan atau memilih } \\
\text { kegiatan sesuai kemampuan } \\
\text { c. Melatih kegiatan sesuai } \\
\text { kemampuan yang dipilih 1 } \\
\text { 4. RTL: } \\
\text { Sp 3: Melatih kegi atan } \\
\text { sesuai kemampuan yang } \\
\text { dipilih 2 }\end{array}$ & \\
\hline $\begin{array}{c}\text { Sabtu, } 20 \text { Maret } 2021 \text { 10:30 } \\
\text { WIB }\end{array}$ & $\begin{array}{l}\text { 1. Data: } \\
\text { Tanda dan gejala : Hilang } \\
\text { kepercayaan diri, merasa } \\
\text { gagal karena tidak mampu } \\
\text { mencapai keinginan sesuai } \\
\text { ideal diri, perasaan tidak } \\
\text { berharga, tidak berarti dan } \\
\text { rendah diri yang } \\
\text { berkepanjangan } \\
\text { 2. Diagnosa Keperawatan } \\
\text { Harga Diri Rendah } \\
\text { 3. Tindakan keperawatan: } \\
\text { Sp 3 Harga Diri Rendah : } \\
\text { Melatih kegiatan sesuai } \\
\text { kemampuan yang dipilih } 2 \\
\text { 4. RTL: } \\
\text { Sp } 4 \text { : Melatih kegiatan } \\
\text { sesuai kemampuan yang } \\
\text { dipilih } 3\end{array}$ & $\begin{array}{l}\text { S : Senang dan antusias } \\
\text { O : Pasien mampu melatih } \\
\text { kegiatan sesuai kemampuan } \\
\text { yaitu menyuci piring dengan } \\
\text { mandiri. } \\
\text { A : Harga Diri Rendah (+) } \\
\text { P : } \\
\text { - Berdoa, Mengikuti ibadah } \\
\text { - Membantu Masak } \\
\text { - Menyuci piring }\end{array}$ \\
\hline $\begin{array}{c}\text { Selasa,22 Maret } 202111.00 \\
\text { WIB }\end{array}$ & $\begin{array}{l}\text { 1. Data: } \\
\text { Tanda dan gejala : Hilang } \\
\text { kepercayaan diri, merasa } \\
\text { gagal karena tidak mampu } \\
\text { mencapai keinginan sesuai } \\
\text { ideal diri, perasaan tidak } \\
\text { berharga, tidak berarti dan } \\
\text { rendah diri yang } \\
\text { berkepanjangan } \\
\text { 2. Diagnosa Keperawatan } \\
\text { Harga Diri Rendah } \\
\text { 3. Tindakan keperawatan: } \\
\text { Sp 4 Harga Diri Rendah : } \\
\text { Melatih kegiatan sesuai } \\
\text { kemampuan yang dipilih } 3 \\
\text { RTL : }\end{array}$ & $\begin{array}{l}\text { S : Senang } \\
\text { O : Pasien mampu melatih } \\
\text { kegiatan sesuai kemampuan } \\
\text { yang dipilih yaitu menyapu } \\
\text { rumah dengan mandiri } \\
\text { A : Harga diri rendah (+) } \\
\text { P : } \\
\text { - Berdoa, Mengikuti ibadah } \\
\text { - Membantu Masak } \\
\text { - Menyuci piring • Menyapu } \\
\text { Halaman }\end{array}$ \\
\hline
\end{tabular}




\begin{tabular}{|l|l|l|}
\hline & $\begin{array}{l}\text { Harga Diri Rendah : Follow } \\
\text { up dan evaluasi SP 1-4 }\end{array}$ & \\
\hline
\end{tabular}

\begin{tabular}{|c|c|c|}
\hline Hari/tgl & Implementasi & Evaluasi \\
\hline $\begin{array}{c}\text { selasa, } 23 \text { Maret } 2021 \text { 10:30 } \\
\text { WIB }\end{array}$ & $\begin{array}{l}\text { 1. Data: } \\
\text { Tanda dan gejala : mudah } \\
\text { marahmarah, } \\
\text { tersinggung,tatapan sinis, } \\
\text { suka menyendiri, merasa } \\
\text { tidak dihargai } \\
\text { 2. Diagnosa Keperawatan } \\
\text { Risiko Perilaku Kekerasan } \\
\text { Harga Diri Rendah } \\
\text { 3. Tindakan keperawatan: } \\
\text { Sp 1 Risiko Perilaku } \\
\text { Kekerasan: } \\
\text { - Mengidentifikasi penyebab } \\
\text { risiko perilaku kekerasan } \\
\text { yaitu jika kemauan pasien } \\
\text { tidak dituruti } \\
\text { - Mengidentifikasi tanda dan } \\
\text { gejala risiko perilaku } \\
\text { kekerasan yaitu pasien } \\
\text { marah, mengamuk tanpa } \\
\text { jelas, merusak barang- } \\
\text { barang, dan cenderung } \\
\text { melukai orang lain } \\
\text { - Menyebutkan } \\
\text { mengontrol risiko perilaku } \\
\text { kekerasan adalah dengan } \\
\text { latihan fisik } 1 \text { tarik napas } \\
\text { dalam latihan fisik } 2 \text { : pukul } \\
\text { kasur bantal } \\
\text { - Membantu pasien latihan } \\
\text { tarik napas dalam dan pukul } \\
\text { kasur bantal. } \\
\text { 4. RTL: Pan } \\
\text { Sp2 Risiko Perilaku } \\
\text { Kekerasan: } \\
\text { - Mengontrolrisiko perilaku } \\
\text { kekerasan dengan minum } \\
\text { obat secara teratur }\end{array}$ & $\begin{array}{l}\text { S : antusias dan bersemangat } \\
\text { O : } \\
\text { - Pasien mampu melakukan } \\
\text { latihan fisik tarik nafas dalam } \\
\text { dengan mandiri } \\
\text { - Pasien mampu pukul kasur } \\
\text { bantal dengan mandiri } \\
\text { - } \\
\text { A : Risiko Perilaku kekerasan } \\
\text { (+) } \\
\text { P : Latihan fisik: } \\
\text {-Tarik nafas dalam } 1 \mathrm{x} / \text { hari } \\
\text {-Pukul kasur bantal } 1 \mathrm{x} / \text { hari }\end{array}$ \\
\hline
\end{tabular}

\begin{tabular}{|c|c|c|}
\hline Hari/tgl & Implementasi & Evaluasi \\
\hline $\begin{array}{c}\text { Rabu, } 24 \text { Maret } 2021 \text { 10:30 } \\
\text { WIB }\end{array}$ & $\begin{array}{l}\text { 1. Data: } \\
\text { Tanda dan gejala : pasien } \\
\text { tanpat katakutan dan merasa } \\
\text { cemas dengan suara yang }\end{array}$ & $\begin{array}{l}\mathrm{S}: \text { pasien mengatakan lebih } \\
\text { tenang dan tidak takut } \\
\mathrm{O}:\end{array}$ \\
\hline
\end{tabular}




\begin{tabular}{|c|c|c|}
\hline & 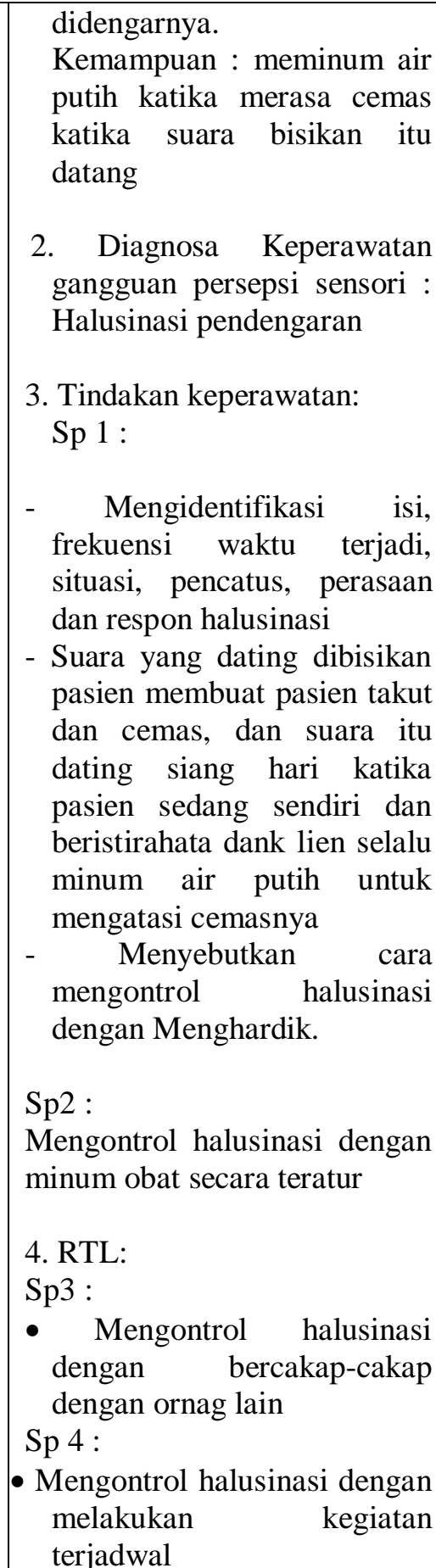 & $\begin{array}{l}\text { - Pasien mampu melakukan } \\
\text { tindakan menghardik dengan } \\
\text { mandiri } \\
\text { - Pasien tampak tenang } \\
\text { - Pasien mau minum obat secara } \\
\text { teratur dengan mandiri } \\
\text { A: Halusinasi Pendegaran (+) } \\
\text { P : Latihan mengontrol } \\
\text { halusinasi dengan cara } \\
\text { menghardik 3x sehari }\end{array}$ \\
\hline $\begin{array}{c}\text { kamis, } 25 \text { Maret } 2021 \text { 10:00 } \\
\text { WIB }\end{array}$ & $\begin{array}{l}\text { 1. Data: } \\
\text { Tanda dan gejala : pasien } \\
\text { tanpat katakutan dan merasa } \\
\text { cemas dengan suara yang } \\
\text { didengarnya. } \\
\text { Kemampuan : meminum air } \\
\text { putih katika merasa cemas } \\
\text { katika suara bisikan itu } \\
\text { datang } \\
\text { 2. Diagnosa Keperawatan }\end{array}$ & $\begin{array}{l}\text { S : pasien mengatakan senang } \\
\text { bisa melakukan kegiatan } \\
\text { tersebut } \\
\text { O : Pasien mampu melakukan } \\
\quad \text { kegiatan tersebut } \\
\text { A: Halusinasi pendengaran }(+) \\
\text { P : }\end{array}$ \\
\hline
\end{tabular}




\begin{tabular}{|c|c|c|}
\hline & 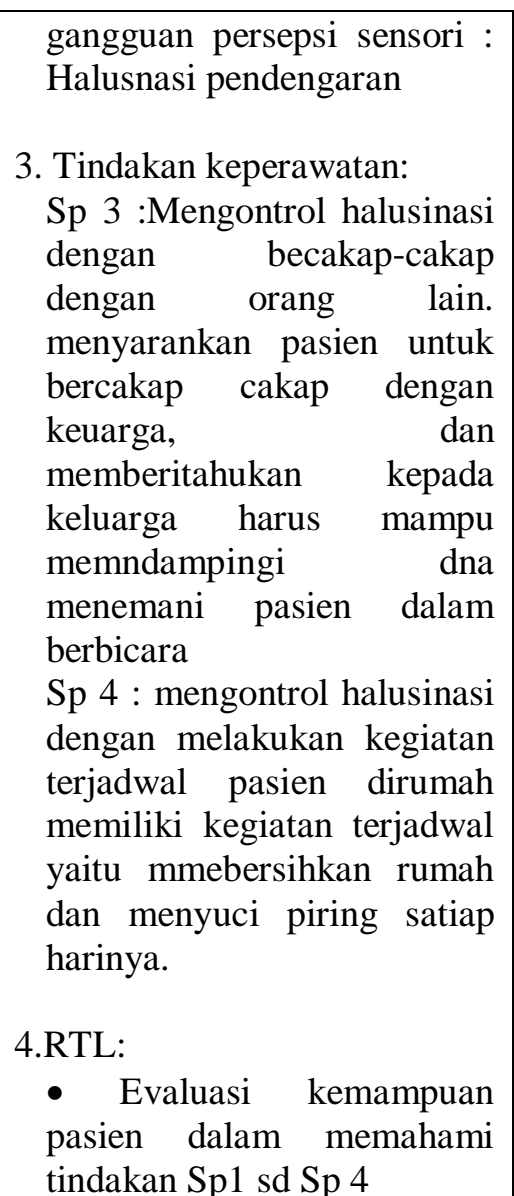 & $\begin{array}{ll}\text { - Bercakap cakap } & \text { dengan } \\
\text { orang lain, } & \text { (sesering } \\
\text { mungkin) } & \\
\text { - Melakukan } & \text { kegiatan } \\
\text { terjadwal melipat } & \text { pakaian( } \\
\text { siang). } & \end{array}$ \\
\hline $\begin{array}{c}\text { kamis, } 25 \text { Maret } 2021 \text { 10:30 } \\
\text { WIB }\end{array}$ & $\begin{array}{l}\text { 1. mengevaluasi kemampuan } \\
\text { pasien dalam mengontrol } \\
\text { halusinasi dengan cara } \\
\text { menghardik } \\
\text { 2. mengevaluasi pasien } \\
\text { menontrol halusinasi } \\
\text { bercakap-cakap dengan } \\
\text { orang lain } \\
\text { 3. mengontrol halusinasi } \\
\text { dengan melakukan kegiatan } \\
\text { terjadwal }\end{array}$ & $\begin{array}{l}\text { S : pasien mengatakan merasan } \\
\text { baik, dan tidak cemas satelah } \\
\text { melakukan kegiatan beberapa } \\
\text { hari ini } \\
\text { O : Pasien mampu melakukan } \\
\text { kegiatan menghardik dengan } \\
\text { mandiri } \\
\text { A : Halisinasi pendengaran } \\
\text { P : Pasien melakukan kegiatan } \\
\text { satiap hari dan siang hari }\end{array}$ \\
\hline
\end{tabular}




\section{BAB 4}

\section{PEMBAHASAN}

Setelah penulis melaksanakan asuhan keperawatan kepada Ny.M dengan Isolasi Sosial di Desa Dahana Kota Gunungsitoli, maka penulis pada BAB ini akan membahasan kesenjangan antara teoritis dengan tinjauan kasus. Pembahasan dimulai melalui tahapan proses keperawatan yaitu pengkajian, diagnosa keperawatan, perencanaan, pelaksanaan dan evaluasi.

\subsection{Tahap Pengkajian}

Selama pengkajian dilakukan pengumpulan data dari beberapa sumber yaitu dari pasien dan pengawas yayasan. Mahasiswa mendapat sedikit kesulitan dalam menyimpulkan data kerena keluarga pasien jarang mengkunjungi pasien di yayasan pemenang jiwa. Maka mahasiwa melakukan pendekatan pada pasien melalui komunikasi terapautik yang lebih terbuka membantu pasien untuk memecahkan perasaannya dan juga melakukan observasi kepada pasien. Adapau upaya tersebut yaitu :

1. Melakukan pendekatan dan membina hubungan saling percaya diri pada pasien agar pasien lebih terbuka dan lebih percaya dengan menggunakan perasaan.

2. Mengadakan pengkajian pasien dengan wawancara dan tidak menemukan kesenjangan karena di temukan hal sama seperti diteori bahwasanya Isolasi sosial meruakan keadaan dimana sseorang individu mengalami penurunan atau bahkan sama sekali tidak mampu berinteraksi dengan orang lain disekitarnya. Pasien isolasi soasial mengalami gangguan dalam berinteraksi dan mengalami perilaku tidak ingin berkomunikasi dengan orang lain disekitarnya, lebih menyukai berdiam diri, mengurung diri, dan menghindar dari orang lain (Pardede, Simanjuntak \& Laia, 2020).

\subsection{Tahap Perencanaan}

Perencanaan dalam proses keperawatan lebih dikenal dengan rencana asuhan keperawatan yang merupakan tahap selanjutnya setelah pangkajian dan penentuan diagnosa keperawatan. Pada tahap perencanaan penulis hanya menyusun rencana tindakan keperawatan sesuai dengan pohon masalah keperawatan yaitu : isolasi sosial. Pada tahap ini antara tinjauan teoritis dan tinjaun kasus tidak ada kesenjangan sehingga penulis dapat melaksanakan tindakan seoptimal mungkin dan didukung dengan seringnya bimbingan dengan pembimbing. Secara teoritis digunakan cara strategi pertemuan sesuai dengan diagnosa keperawatan yang muncul saat pengkajian. Adapun upaya yang dilakukan penulis yaitu : 


\section{Isolasi Sosial}

a. Mengidentifikasi isi Isolasi Sosial

b. Mengidentifikasi waktu terjadi Isolasi Sosial

c. Mengidentifikasi situasi pencetus Isolasi Sosial

d. Mengidentifikasi respon terhadap Isolasi Sosial

e. Membantu pasien mempraktekan latihan cara berkenalan dengan dua orang atau lebih

f. Menjelaskan keutungan dan kerugian mempunya teman

g. Melatih pasien bercakap - cakap sambil melakukan kegiatan harian

h. Melatih pasien berbicara soial : seperti meminta sesuatu, berbelanja dan sebagainya

i. Mengevaluasi jadwal kegiatan harian pasien

\subsection{Tahap Implementasi}

Pada tahap implementasi, penulis hanya mengatasi 1 masalah keperawatan yakni: diagnosa keperawatan Isolasi Sosial di karenakan masalah utama yang dialami pasien. Pada diagnosa keperawatan Isolasi dilakukan strategi pertemuan yaitu mengidentifikasi isolasi sosial, menjelaskan keuntungan dan kerugian mempunyai teman,. Strategi pertemuan yang kedua yaitu membantu pasien mempratekkan cara berkenalan dengan dua orang atau lebih, strategi pertemuan ketiga yaitu melatih pasien bercakap cakap sambil melakukan kegiatan harian, pertemuan ke empat yaitu melatih pasien berbicara sosial seperti meminta bantuan, belanja, dan sebgainya ( Wahyu, 2021)

\subsection{Tahap Evlaluasi}

Pada tinjauan teoritis evaluasi yang diharapkan adalah :

1. Pasien mempercayai perawat sebagai terapis

2. Dapat mengidentifikasi dan mengontrol Isolasi Sosial

3. Dapat mengendalikan Isolasi Sosial melalui berkenalan dengan dua orang atau lebih

4. Dapat mengendalikan Isolasi Sosial dengan cara bercakap cakap sambil melakukan kegiatan harian.

5. Dapat mengendalikan Isolasi Sosial dengan cara berbicara sosial seperti : meminta bantuan, berbelanja, dan lain sebagainya.. 
Pada tinjauan kasus evaluasi yang dihasilkan adalah :

1. Pasien sudah dapat mengontrol dan mengidentifikasi Isolasi Sosial

2. Pasien dapat mengendalikan Isolasi Sosial melalui berkenalan dengan dua orang atau lebih.

3. Pasien dapat mengendalikan Isolasi Sosial dengan cara bercakap cakap sambil melakukan kegiatan harian. Pasien dapat mengendalikan Isolasi Sosial dengan cara berbicara sosial seperti: meminta bantuan, berbelanja, dan lain sebagainya 


\section{BAB 5}

\section{PENUTUP}

\subsection{Kesimpulan}

Setelah menguraikan tentang proses keperawatan pada Ny.M dan disimpulkan bahwa pasien dapat mengontrol Isolasi Sosial dengan terapi yang di ajarkan oleh mahasiwa. Dimana pasien suda dapat mengetahui keuntungan dan kerugian mempunyai teman,dapat melakukan cara berkenalan dengan dua orang atau lebih, bercakap cakap sambil melakukan kegiatan harian, berbicara sosial seperti : meminta sesuatu, belanja dan sebagainya dan dilakukan dalam kegiatan harian pasien di Yayasan

\subsection{Saran}

1. Bagi pasien hendaknya dapat berinteraksi sosial dengan menerapkan strategi pelaksanaan,menyadari keuntungan memiliki teman dan kerugian tidak memiliki teman, melakukan komunikasi kepada sesama atau dilingkungan sekitar, meminum obat secara teratur dan dapat berinteraksi sosial seperti meminta sesuatu kepada teman atau dilingkungan sekitar.

2. Bagi yayasan pemenang jiwa sumatera hendaknya memberikan pelayanan kesehatan yang baik dan membuat suasana lingkungan menjadi lebih nyaman agar pasien mampu bersosialisasi dengan orang lain yang berada disekitar lingkungannya. 


\section{DAFTAR PUSTAKA}

1. Astuti, L. (2020). Studi Dokumentasi Isolasi Sosial Pada Pasien Dengan Skizofrenia. Akademi Keperawatan YKY Yogyakarta. http://repository.akperykyjogja.ac.id/id/eprint/295

2. Pardede, J. A., Ariyo, A., \& Purba, J. M. (2020). Self Efficacy Related to Family Stress in Schizophrenia Patients. Jurnal Keperawatan, 12(4), 831-838.

2. Kirana, S. (2018). Gambaran Kemampuan Interaksi Sosial Pasien Isolasi Sosial Setelah Pemberian Social Skills Therapy Di Rumah Sakit Jiwa. Journal of Health Sciences, 11(1). https://doi.org/10.33086/jhs.v11i1.122

3. Pardede, J. A., \& Ramadia, A. (2021). The Ability to Interact with Schizophrenic Patients through Socialization Group Activity Therapy. INTERNATIONAL JOURNAL OF CONTEMPORARY MEDICINE, 9(1), 6. https://doi.org/10.37506/ijocm.v9i1.2925

4. Pardede, J. A. (2017). The Implementation of Family Tasks with The Frequency of Recurrence of Social Isolation Patients. Mental Health, 4(2).

5. Banjar, B. R. S. U. K., \& Maulana, K.(2016). Asuhan keperawatan pada ny. R dengan isolasi sosial: menarik diri akibat skizofrenia di ruang tanjung. http://cdn.stikesmucis.ac.id/13DP277033.

6. Damanik, R. K., Pardede, J. A., \& Manalu, L. W. (2020). Terapi Kognitif Terhadap Kemampuan Interaksi Pasien Skizofrenia Dengan Isolasi Sosial. Jurnal Ilmu Keperawatan dan Kebidanan, 11(2), 226-235. http://dx.doi.org/10.26751/jikk.v11i2.822

7. Enggar, A. (2020). Studi Literatur: Asuhan Keperawatan Pada Pasien Skizofrenia Dengan Masalah Keperawatan Isolasi Sosial Menarik Diri (Doctoral dissertation, Universitas Muhammadiyah Ponorogo).

8. Fitria. (2019). Buku Ajar Keperawatan Jiwa (Advance Mental Health Nursing). Bandung : Refika Aditama. https://onesearch.id/Record/IOS3318.

9. Gaol, H. L. (2021). Asuhan Keperawatan Jiwa Pada Ny. I Dengan Masalah Halusinasi Pendengaran. doi. 10.31219/osf.io/r5anf 
10. Habeahan, H. (2020). Perencanaan Keperawatan Dalam Proses Menentukan Diagnosa Keperawatan Dengan Melakukan Cara Berpikir Kritis. https://osf.io/5y3gm/download?format=pdf

11. Hasriana, H., Nur, M., \& Anggraini, S. (2013). Pengaruh terapi aktivitas kelompok sosialisasi terhadap kemampuan bersosialisasi pada pasien isolasi sosial menarik diri di Rumah Sakit Khusus Daerah Provinsi Sulawesi Selatan. Jurnal Ilmiah Kesehatan Diagnosis, 2(6), 74-79. http://ejournal.stikesnh.ac.id/index.php/jikd/article/view/485

12. Hermawan, B. (2015). Asuhan Keperawatan Jiwa Pada Tn. S Dengan Gangguan Isolasi Sosial: Menarik Diri Di Ruang Arjuna RSJ Daerah Surakarta (Doctoral dissertation, Universitas Muhammadiyah http://eprints.ums.ac.id/id/eprint/34432.

13. Kurniasari, C. I., Dwidiyanti, M., \& Padmasari, S. (2019). Terapi Keperawatan Dalam Mengatasi Masalah Interaksi Sosial pada Pasien Skizofrenia: Literatur Review. Jurnal Ilmu Keperawatan Jiwa, 2(1), 41-46. http://dx.doi.org/10.32584/jikj.v2i1.276

14. Latifah, L., \& Rahayu, P. (2020). Pengaruh terapi social skill training tahap melatih kemampuan berkomunikasi pada pasien skizofrenia. Jurnal'Aisyiyah Medika, 5(1). https://doi.org/10.36729/jam.v5i1.308

15. Muhith, A. (2015). Pendidikan Keperawatan Jiwa : Teori dan Aplikasi. Penerbit Andi.

16. Pardede, J. A. (2018). Pelaksanaan Tugas Keluarga Dengan Frekuensi Kekambuhan Pasien Skizofrenia Dengan Masalah Isolasi Sosial. Jurnal Keperawatan Jiwa, 6(2).

17. Pardede, J. A., Simanjuntak, G. V., \& Laia, R. (2020). The Symptoms of Risk of Violence Behavior Decline after Given Prgressive Muscle Relaxation Therapy on Schizophrenia Patients. Jurnal Ilmu Keperawatan Jiwa, 3(2), 91-100. http://dx.doi.org/10.32584/jikj.v3i2.534

18. Pardede, J. A., Hamid, A. Y. S., \& Putri, Y. S. E. (2020). Application of Social Skill Training using Hildegard Peplau Theory Approach to Reducing Symptoms and the Capability of Social Isolation Patients. Jurnal Keperawatan, 12(3), 327-340 https://doi.org/10.32583/keperawatan.v12i3.782

19. Pardede, J. A., \& Laia, B. (2020). Decreasing Symptoms of Risk of Violent Behavior in Schizophrenia Patients Through Group Activity Therapy. Jurnal Ilmu Keperawatan Jiwa, 3(3), 291-300. http://dx.doi.org/10.32584/jikj.v3i3.621

20. Rahmadani, K. D. (2019). Asuhan Keperawatan Jiwa Pada Pasien Dengan Perilaku Kekerasan Di Ruang Tiung Rumah Sakit Jiwa Daerah Atma Husada Mahakam Samarinda. http://repository. poltekkes-kaltim.ac.id/id/eprint/402 
21. Siskayanti, A., Nugroho, A., \& Hartoyo, M. (2012). Pengaruh terapi komunikasi terapeutik terhadap kemampuan berinteraksi pasien isolasi sosial di rsjd dr. Amino gondohutomo semarang. Karyallmiah. http://eprints.umpo.ac.id/id/eprint/6170

22. Sukaesti, D. (2019). Sosial Skill Training Pada Pasien Isolasi Sosial. Jurnal Keperawatan Jiwa, 6(1), 19-24.https://doi.org/10.26714/jkj.6.1.2018.19-24

23. Suciati, N. M. A. (2019). Gambaran Asuhan Keperawatan Pemberian Tak Sosialisasi Sesi 2: Kemampuan Berkenalan Untuk Mengatasi Isolasi Sosial Pada Pasien Skizofrenia Tahun 2019 (Doctoral dissertation, Politeknik Kesehatan Kemenkes Denpasar Jurusan Keperawatan). http://repository.poltekkesdenpasar.ac.id/id/eprint/2369

24. Sumarno, K. (2019). Asuhan Keperawatan Pada Tn. FPB Dengan Isolasi Sosial: Menarik Diri Di Ruang Rawat Inap Rumah Sakit Jiwa Naimata Kupang Provinsi Nusa Tenggara Timur. Skripsi, Poltekkes Kemenkes Kupang.

25. Sutejo. (2017). Konsep dan Praktik Asuhan Keperawatan Kesehatan Jiwa: Ganguan Jiwa dan Psikososial. Yogyakarta: PT. Pustaka Baru.

26. Manao, B. M., \& Pardede, J. A. (2019). Correlation of Family Burden of The Prevention of Recurrence of Schizophrenia Patients. Mental Health, 4(1), 31-42.

27. Riskiyani, R. (2021). Asuhan Keperawatan Pada Gangguan Jiwa Dengan Pasien Isolasi Sosial. Universitas Kusuma Husada Surakarta. http://eprints.ukh.ac.id/id/eprint/1471 